\title{
Science and Mathematics Teaching Efficacy Beliefs of Pre-school Teachers*
}

\author{
Bülent Aydoğdu*, Murat Peker \\ Department of Mathematics and Science Education, Afyon Kocatepe University, Turkey
}

Copyright $\mathrm{C} 2016$ by authors, all rights reserved. Authors agree that this article remains permanently open access under the terms of the Creative Commons Attribution License 4.0 International License

\begin{abstract}
The aim of this research was to examine science and mathematics teaching efficacy beliefs of pre-school teachers in terms of some variables. The sample of the study was comprised of 191 pre-school teachers working in a city in Aegean Region of Turkey. Since it attempted to define self-efficacy beliefs of pre-school teachers toward science and mathematics teaching, the relational screening model was used. Developed by Riggs and Enochs [1] and adapted by Özkan, Tekkaya and Çakıroğlu [2], "The Scale of Self-Efficacy in Science Teaching" and adapted for mathematics teaching by Dede [3], "The Scale of Self-Efficacy in Mathematics Teaching" was used to collect data in the study. The results indicated that the self-efficacy beliefs of the teachers toward mathematics and science teaching differed regarding their graduation program and the time period that was allocated for science and mathematics activities.
\end{abstract}

Keywords Self-efficacy Beliefs, Pre-school Teachers, Science Teaching, Mathematics Teaching

\section{Introduction}

It is clear that the beliefs of individuals on their abilities shape their behaviors [4]. Furthermore, teachers have a key role on the application of curricula [5]. Since teachers regulate their teaching through their positive and negative beliefs, the beliefs of teachers towards any course are highly important. Therefore, maximizing the self-efficacy of teachers is one of the ways to increase the effectiveness of the education and instruction ([6]; [7]). In the literature, the self-efficacy concept has been described many times. According to Flores [8], self-efficacy is one's belief or judgment about his or her ability to complete certain tasks. According to Dede [3], self-efficacy belief is one of the major factors having an effect on mathematics teaching and it has a significant role in the development of human behavior due to its effect on behaviors. Mathematics self-efficacy is defined as the belief of individuals on their capabilities to conduct mathematical issues successfully [9].
The self-efficacy toward science teaching can be described as the judgment and beliefs of the teachers on the ability to conduct science education effectively and increase the achievement of students [10]. It is of importance for teachers to believe that they can teach science at a good level and love their job without any concern [11].

On the other hand, the content knowledge of teachers toward professional development has a positive effect on teachers' beliefs and self-efficacy for teaching [12]. Also, the teachers who have high self-efficacy perception create a better classroom environment and aid their students to improve literacy skills ([13]; [14]; [15]). Pajares and Kranzler [9] stated that mathematics self-efficacy had a significant effect on mathematics anxiety and problem solving performance. Hackett and Betz [16] found out that mathematics self-efficacy was significantly positively correlated with attitudes toward mathematics and effectance motivation. Dede [3] reported that mathematics teachers' levels of self-efficacy for effective teaching of mathematics and of self-efficacy for teaching are higher than levels of self-efficacy for helping and motivating students towards mathematics. Peker [17] concluded that mathematics teaching anxiety had a significant effect on pre-service primary school teachers' levels of self-efficacy for mathematics teaching. Similarly, primary school science teaching is one area, in which, however, low level of teacher efficacy has long been a problem [18]. That is why science teachers are expected to have high levels of self-efficacy for science teaching. According to Yaman, Cansüngü-Koray and Altunçekiç [19], science teachers with higher levels of self-efficacy successfully tend to use student-centered approaches, spend more time teaching science and bring inquiry-based teaching methods to their classrooms while those with lower levels of self-efficacy prefer teacher-centered methods of instruction, such as lecture.

Science and mathematics are interrelated subjects and have a reciprocal relationship. Mathematics can be considered to be the language of science, and the common goals of the science and mathematics teaching are the development of skills in logical mathematical reasoning and problem-solving ([20], [21]). Science and mathematics go hand in hand and support each other in developing the 
cognitive abilities of individuals [22]. Buss [23] indicated that pre-service primary school teachers had lower levels of self-efficacy for teaching science and mathematics than for teaching other subjects in the primary school curriculum. The children in the pre-school-age have a positive attitude toward learning science [24]. However, the beliefs of teachers on science and mathematics teaching play a significant role in teaching the science and mathematics concepts that are highly crucial for preschoolers. Considering the fact that the pre-school education is the first step in the formal education, it is of importance to determine the self-efficacy beliefs of pre-school teachers toward science and mathematics teaching and to relate in terms of some variables.

Chung, Marvin and Churchill [25] highlighted that pre-school age student achievement is positively correlated with pre-school teachers' self-efficacy. In this regard, it is of great significance to determine self-efficacy levels of pre-school teachers considering the impact of teachers on students ([26]). However, studies on pre-school teachers' self-efficacy ([26], [27]) are few in number. There are also few studies on pre-school teachers' self-efficacy for teaching mathematics or science ([28]; [29]; [30]). But, pre-service pre-school teachers' self-efficacy for teaching mathematics or science is mostly studied ([31]; [32]; [33]; [34]; [35]; [36]; [37] [38]). However, there is no any study on pre-school teachers' self-efficacy beliefs for teaching mathematics and science with together. Another reason for conducting this study is that pre-school teachers are not found competent enough with material development in science and science topics ([39]; [40]). In addition, pre-school teachers encounter some problems with teaching mathematics, and they view learning of mathematics as passively receiving of knowledge ([29]). For this reason, the current study focuses on determining pre-school teachers' levels of self-efficacy for teaching mathematics and science and examining their self-efficacy in terms of some variables. This study is anticipated to be a contribution to the literature.

\subsection{Aim of the Study}

The aim of this study is to examine science and mathematics teaching efficacy beliefs of pre-school teachers in terms of some variables.

The research question and sub-research questions related to the study performed for this aim are given as follows.

\subsection{Research Question}

Do pre-school teachers' science and mathematics teaching efficacy beliefs significantly differ on seniority, department that they graduated from university; time allocated for science and mathematics activities per week, and workplace?

\subsection{Sub-Research Questions}

1. What are these pre-school teachers' science and mathematics teaching efficacy levels?
2. Do these pre-school teachers' science and mathematics teaching efficacy beliefs significantly differ depending on seniority?

3. Do these pre-school teachers' science and mathematics teaching efficacy beliefs significantly differ depending on the department that they graduated from university?

4. Do pre-school teachers' science and mathematics teaching efficacy beliefs significantly differ depending on time allocated for science and mathematics activities per week?

5. Do pre-school teachers' science and mathematics teaching efficacy beliefs significantly differ depending on the workplace?

\subsection{Hypotheses}

For the $2^{\text {nd }}$ sub-research question,

$\mathrm{H}_{0}$ : Pre-school teachers' science and mathematics teaching efficacy beliefs do not significantly differ depending on seniority.

$\mathrm{H}_{1}$ : Pre-school teachers' science and mathematics teaching efficacy beliefs significantly differ depending on seniority.

For the $3^{\text {rd }}$ sub-research question,

$\mathrm{H}_{0}$ : Pre-school teachers' science and mathematics teaching efficacy beliefs do not significantly differ depending on the department they graduated from university.

$\mathrm{H}_{1}$ : Pre-school teachers' science and mathematics teaching efficacy beliefs significantly differ depending on the department they graduated from university.

For the $4^{\text {th }}$ sub-research question,

$\mathrm{H}_{0}$ : Pre-school teachers' science and mathematics teaching efficacy beliefs do not significantly differ depending on time allocated for science and mathematics activities per week.

$\mathrm{H}_{1}$ : Pre-school teachers' science and mathematics teaching efficacy beliefs significantly differ depending on time allocated for science and mathematics activities per week.

For the $5^{\text {th }}$ sub-research question,

$\mathrm{H}_{0}$ : Pre-school teachers' science and mathematics teaching efficacy beliefs do not significantly differ depending on the workplace.

$\mathrm{H}_{1}$ : Pre-school teachers' science and mathematics teaching efficacy beliefs significantly differ depending on the workplace.

\section{Materials and Methods}

\subsection{Research Design}

Since the study attempted to identify science and mathematics teaching efficacy beliefs of pre-school teachers, the relational screening model was used in the current study [41]. 


\subsection{Research Sample}

The sample of the study was comprised of 191 pre-school teachers working in a city in Aegean Region of Turkey. Distribution of the participants regarding their gender, seniority, department that they graduated from university and workplace is presented in Table 1.

Table 1. Distribution of participants regarding gender, seniority, graduation program, and workplace variables

\begin{tabular}{|c|c|c|c|}
\hline \multirow{4}{*}{ Gender } & & $\mathrm{N}$ & $\%$ \\
\cline { 2 - 4 } & Female & 188 & 98 \\
\cline { 2 - 4 } & Male & 3 & 2 \\
\hline \multirow{4}{*}{ Seniority } & Total & 191 & 100 \\
\cline { 2 - 4 } & $0-5$ years & 45 & 24 \\
\cline { 2 - 4 } & 6-10 years & 89 & 47 \\
\cline { 2 - 4 } & $11-15$ years & 37 & 19 \\
\cline { 2 - 4 } & 16 and more years & 20 & 10 \\
\hline \multirow{4}{*}{$\begin{array}{c}\text { Graduation } \\
\text { program }\end{array}$} & Total & 191 & 100 \\
\cline { 2 - 4 } & Pre-school Teacher Education & 138 & 72 \\
\cline { 2 - 4 } & Distance Pre-school Teacher & 21 & 11 \\
\cline { 2 - 4 } & Education & 32 & 17 \\
\hline \multirow{3}{*}{ Workplace } & Total & 191 & 100 \\
\cline { 2 - 4 } & Rural & 36 & 19 \\
\cline { 2 - 4 } & Urban & 191 & 100 \\
\hline
\end{tabular}

\subsection{Instruments}

\subsubsection{Science Teaching Efficacy Belief Instrument (STEBI)}

STEBI was developed by Riggs and Enochs [1] and was adapted to Turkish by Özkan, Tekkaya and Çakıroğlu [2]. The STEBI that was prepared as a five point Likert type scale was composed of 23 items and of two sub-dimensions which were "personal self-efficacy belief in science teaching" and "result expectation in science teaching". The "personal self-efficacy belief in science teaching" dimension consisted of 13 items while the "result expectation in science teaching" dimension was composed of 10 items. Cronbach Alpha reliability coefficient of the STEBI adapted to Turkish by Özkan, Tekkaya, and Çakıroğlu [2] was .79 for the first sub-dimension and .86 for the second. In the current study, the value calculated for the first sub-dimension was .74, the value for the second was .76 , and the value for full items was .87 .

\subsubsection{Mathematics Teaching Efficacy Belief Instrument (MTEBI)}

MTEBI which was adapted for mathematics teaching by Dede [3] from STEBI belonging to Riggs and Enochs [1] was used in the current study. The MTEBI that was prepared as a five point Likert type scale was composed of 14 items and of three sub-dimensions which were "efficacy in mathematics teaching", "motivation and taking responsibility in mathematics teaching", and "effective mathematics teaching". The sub-dimensions of the MTEBI consisted of 4, 6, and 4 items, respectively. Cronbach Alpha reliability coefficient of the MTEBI adapted for mathematics teaching by Dede [3] was .80. In the current study, the value calculated for the first sub-dimension was .77 , the value for the second one was .65 , the value for the third one was .83 , and the value for full items was .88 .

\subsection{Data Analysis}

SPSS packet program was used for the analysis of data gained after the applications. Data analysis was done with a one-way MANOVA procedure. MANOVA is used to test whether more than one dependent variable significantly differs in independent groups ([42]). Since the current study included more than one dependent variable (i.e. STEBI with two levels and MTEBI with three levels), MANOVA was preferred for data analysis. To determine which groups were significantly different from each other, Tukey's HSD test was performed ([42]).

\section{Findings}

This study examined in detail pre-school teachers' self-efficacy beliefs toward science and mathematics instruction in terms of some variables (seniority, their department that they graduated from university, time allocated for science and mathematics activities per week, and workplace) with a one-way MANOVA procedure. The scores that pre-school teachers obtained from STEBI and MTEBI are presented in Table 2.

Table 2. Scores that pre-school teachers obtained from STEBI and MTEBI

\begin{tabular}{|c|c|c|c|c|}
\hline Instruments & All sub-dimensions & $\mathrm{N}$ & Mean & $\mathrm{SD}$ \\
\hline \multirow{3}{*}{$\begin{array}{c}\text { Science Teaching Efficacy Belief } \\
\text { Instrument (STEBI) }\end{array}$} & Personal self-efficacy belief in science teaching & 191 & 3.85 & .54 \\
\hline & Result expectation in science teaching & 191 & 3.76 & .55 \\
\hline & Total & 191 & 3.81 & .51 \\
\hline \multirow{4}{*}{$\begin{array}{l}\text { Mathematics Teaching Efficacy Belief } \\
\text { Instrument (MTEBI) }\end{array}$} & Efficacy in mathematics teaching & 191 & 3.96 & .87 \\
\hline & Motivation and taking responsibility in mathematics teaching & 191 & 3.63 & .68 \\
\hline & Effective mathematics teaching & 191 & 3.98 & .89 \\
\hline & Total & 191 & 3.83 & .70 \\
\hline
\end{tabular}


The results of one-way MANOVA test performed to determine whether seniority had an effect on pre-school teachers' STEBI and MTEBI scores are presented in Table 3.

Table 3. The results of one-way MANOVA test performed to determine whether there was a difference at STEBI and MTEBI scores of pre-school teachers according to their seniority

\begin{tabular}{|c|c|c|c|c|c|c|c|c|}
\hline Instrument & \multicolumn{2}{|c|}{ Effect } & Values & $\mathrm{F}$ & Hypothesis df & Error df & $\mathrm{p}$ & $\eta^{2}$ \\
\hline STEBI & \multirow{2}{*}{ Seniority } & \multirow{2}{*}{ Wilks' Lambda } & 0.933 & 1.446 & 9.000 & 450.392 & .166 & .023 \\
\hline MTEBI & & & 0.971 & 0.904 & 6.000 & 372.000 & .492 & .014 \\
\hline
\end{tabular}

As seen in Table 3, there was no a significant difference both STEBI and MTEBI scores of pre-school teachers according to their seniority [Wilks Lambda $(\Lambda)=0.933, \mathrm{~F}(9,450)=1.446, \mathrm{p}=0.166, \eta^{2}=0.023$ for STEBI; Wilks Lambda $(\Lambda)=0.971, \mathrm{~F}(6$, $372)=0.904, p=0.492, \eta^{2}=0.014$ for MTEBI ]. One-way MANOVA analysis for STEBI and MTEBI scores of pre-school teachers according to their seniority is presented in Table 4.

Table 4. One-way MANOVA analysis for STEBI scores of pre-school teachers according to their seniority

\begin{tabular}{|c|c|c|c|c|c|c|c|c|c|}
\hline Instruments & Sub-dimensions & Seniority & $\mathrm{N}$ & $\mathrm{M}$ & SD & $\mathrm{Df}$ & $\mathrm{F}$ & $\mathrm{p}$ & $\eta^{2}$ \\
\hline \multirow{15}{*}{ STEBI } & \multirow{5}{*}{$\begin{array}{l}\text { Personal self-efficacy } \\
\text { belief in science } \\
\text { teaching }\end{array}$} & $0-5$ years & 45 & 3.75 & .64 & \multirow{5}{*}{187} & \multirow{5}{*}{.920} & \multirow{5}{*}{.432} & \multirow{5}{*}{.015} \\
\hline & & $6-10$ years & 89 & 3.86 & .49 & & & & \\
\hline & & $11-15$ years & 37 & 3.94 & .54 & & & & \\
\hline & & 16 and more years & 20 & 3.89 & .52 & & & & \\
\hline & & Total & 191 & 3.85 & .54 & & & & \\
\hline & \multirow{5}{*}{$\begin{array}{l}\text { Result expectation in } \\
\text { science teaching }\end{array}$} & $0-5$ years & 45 & 3.62 & .74 & \multirow{5}{*}{187} & \multirow{5}{*}{1.548} & \multirow{5}{*}{.204} & \multirow{5}{*}{.024} \\
\hline & & $6-10$ years & 89 & 3.77 & .45 & & & & \\
\hline & & $11-15$ years & 37 & 3.83 & .50 & & & & \\
\hline & & 16 and more years & 20 & 3.88 & .49 & & & & \\
\hline & & Total & 191 & 3.76 & .55 & & & & \\
\hline & \multirow{5}{*}{ Total } & $0-5$ years & 45 & 3.69 & .66 & \multirow{5}{*}{187} & \multirow{5}{*}{1.293} & \multirow{5}{*}{.278} & \multirow{5}{*}{.020} \\
\hline & & 6-10 years & 89 & 3.82 & .43 & & & & \\
\hline & & $11-15$ years & 37 & 3.89 & .47 & & & & \\
\hline & & 16 and more years & 20 & 3.88 & .49 & & & & \\
\hline & & Total & 191 & 3.81 & .51 & & & & \\
\hline \multirow{20}{*}{ MTEBI } & \multirow{5}{*}{$\begin{array}{c}\text { Efficacy in } \\
\text { mathematics teaching }\end{array}$} & $0-5$ years & 45 & 3.98 & .97 & \multirow{5}{*}{187} & \multirow{5}{*}{1.039} & \multirow{5}{*}{.372} & \multirow{5}{*}{.016} \\
\hline & & $6-10$ years & 89 & 4.00 & .84 & & & & \\
\hline & & $11-15$ years & 37 & 4.12 & .67 & & & & \\
\hline & & 16 and more years & 20 & 3.68 & 1.20 & & & & \\
\hline & & Total & 191 & 3.98 & .89 & & & & \\
\hline & & $0-5$ years & 45 & 3.60 & .68 & & & & \\
\hline & Motivation and taking & $6-10$ years & 89 & 3.62 & .75 & & & & \\
\hline & responsibility in & $11-15$ years & 37 & 3.74 & .49 & 187 & .452 & .716 & .007 \\
\hline & mathematics teaching & 16 and more years & 20 & 3.54 & .71 & & & & \\
\hline & & Total & 191 & 3.63 & .68 & & & & \\
\hline & & $0-5$ years & 45 & 3.82 & .76 & & & & \\
\hline & & 6-10 years & 89 & 3.91 & .92 & & & & \\
\hline & $\begin{array}{c}\text { Effective mathematics } \\
\text { teaching }\end{array}$ & $11-15$ years & 37 & 4.26 & .64 & 187 & 1.962 & .121 & .031 \\
\hline & & 16 and more years & 20 & 3.97 & 1.14 & & & & \\
\hline & & Total & 191 & 3.96 & .87 & & & & \\
\hline & & $0-5$ years & 45 & 3.77 & .68 & & & & \\
\hline & & 6-10 years & 89 & 3.81 & .74 & & & & \\
\hline & Total & $11-15$ years & 37 & 4.00 & .46 & 187 & 1.014 & .388 & .016 \\
\hline & & 16 and more years & 20 & 3.70 & .90 & & & & \\
\hline & & Total & 191 & 3.83 & .70 & & & & \\
\hline
\end{tabular}

As seen in Table 4, the Tukey's HSD test results showed that seniority had not an effect on pre-school teachers' STEBI and MTEBI scores and on pre-school teachers' scores of all sub-dimensions of STEBI and MTEBI. The results of one-way MANOVA test were performed whether there was a significant difference both STEBI and MTEBI scores of pre-school teachers according to their departments that they graduated from university and the results are presented in Table 5 . 
Table 5. The results of one-way MANOVA test performed to determine whether there was a difference on STEBI and MTEBI scores of pre-school teachers according to their departments that they graduated from university

\begin{tabular}{|c|c|c|c|c|c|c|c|c|}
\hline Instruments & \multicolumn{2}{|c|}{ Effect } & Values & $\mathrm{F}$ & Hypothesis df & Error $\mathrm{df}$ & $\mathrm{p}$ & $\eta^{2}$ \\
\hline STEBI & \multirow{2}{*}{ Graduation program } & \multirow{2}{*}{ Wilks' Lambda } & 0.922 & 3.876 & 4.000 & 374.000 & $.004 *$ & .040 \\
\hline MTEBI & & & 0.939 & 1.475 & 8.000 & 370.000 & .165 & .031 \\
\hline
\end{tabular}

$* \mathrm{p}<0.05$

As seen in Table 5, there was a significant difference at STEBI scores of pre-school teachers according to their departments that they graduated from university [Wilks Lambda $(\Lambda)=0.922, \mathrm{~F}(4,374)=3.876, \mathrm{p}=0.004, \eta^{2}=0.040$ for STEBI] However, there was no significant difference between MTEBI scores of pre-school teachers according to their departments that they graduated from university [Wilks Lambda $(\Lambda)=0.939, \mathrm{~F}(8,370)=1.475, \mathrm{p}=0.165, \eta^{2}=0.031$ for MTEBI]. One-way MANOVA analysis for STEBI and MTEBI scores of pre-school teachers is presented in Table 6 according to their graduation program.

Table 6. The results of one-way MANOVA test performed whether there was a difference both STEBI and MTEBI scores of pre-school teachers according to their departments graduated from university

\begin{tabular}{|c|c|c|c|c|c|c|c|c|c|c|}
\hline Instruments & Sub-dimensions & $\begin{array}{c}\text { Departments graduated from } \\
\text { university }\end{array}$ & $\mathrm{N}$ & M & SD & Df & $\mathrm{F}$ & $P$ & $\eta^{2}$ & Difference \\
\hline \multirow{12}{*}{ STEBI } & \multirow{4}{*}{$\begin{array}{c}\text { Personal } \\
\text { self-efficacy } \\
\text { belief in science } \\
\text { teaching }\end{array}$} & $\begin{array}{l}\text { Pre-school Teacher } \\
\text { Education }\end{array}$ & 38 & 3.92 & .52 & \multirow{4}{*}{188} & \multirow{4}{*}{6.163} & \multirow{4}{*}{$.03 *$} & \multirow{4}{*}{.062} & \multirow{4}{*}{$1-3$} \\
\hline & & Child Development & 21 & 3.90 & .38 & & & & & \\
\hline & & $\begin{array}{c}\text { Distance Pre-school Teacher } \\
\text { Education }\end{array}$ & 32 & 3.55 & .64 & & & & & \\
\hline & & Total & 191 & 3.85 & .54 & & & & & \\
\hline & \multirow{4}{*}{$\begin{array}{c}\text { Result } \\
\text { expectation in } \\
\text { science teaching }\end{array}$} & $\begin{array}{l}\text { Pre-school Teacher } \\
\text { Education }\end{array}$ & 38 & 3.83 & .49 & \multirow{4}{*}{188} & \multirow{4}{*}{7.470} & \multirow{4}{*}{$.01 *$} & \multirow{4}{*}{.074} & \multirow{4}{*}{$\begin{array}{l}1-3 \\
2-3\end{array}$} \\
\hline & & Child Development & 21 & 3.80 & .53 & & & & & \\
\hline & & $\begin{array}{c}\text { Distance Pre-school Teacher } \\
\text { Education }\end{array}$ & 32 & 3.43 & .68 & & & & & \\
\hline & & Total & 191 & 3.76 & .55 & & & & & \\
\hline & \multirow{4}{*}{ Total } & $\begin{array}{l}\text { Pre-school Teacher } \\
\text { Education } \\
\end{array}$ & 38 & 3.88 & .47 & \multirow{4}{*}{188} & \multirow{4}{*}{7.718} & \multirow{4}{*}{$.01 *$} & \multirow{4}{*}{.076} & \multirow{4}{*}{$\begin{array}{l}1-3 \\
2-3\end{array}$} \\
\hline & & Child Development & 21 & 3.85 & .42 & & & & & \\
\hline & & $\begin{array}{c}\text { Distance Pre-school Teacher } \\
\text { Education } \\
\end{array}$ & 32 & 3.50 & .61 & & & & & \\
\hline & & Total & 191 & 3.81 & .51 & & & & & \\
\hline \multirow{16}{*}{ MTEBI } & \multirow{4}{*}{$\begin{array}{l}\text { Efficacy in } \\
\text { mathematics } \\
\text { teaching }\end{array}$} & $\begin{array}{l}\text { Pre-school Teacher } \\
\text { Education } \\
\end{array}$ & 38 & 4.05 & .77 & \multirow{4}{*}{188} & \multirow{4}{*}{4.811} & \multirow{4}{*}{$.009 *$} & \multirow{4}{*}{.049} & \multirow{4}{*}{$\begin{array}{l}1-3 \\
2-3\end{array}$} \\
\hline & & Child Development & 21 & 4.20 & 1.05 & & & & & \\
\hline & & $\begin{array}{c}\text { Distance Pre-school Teacher } \\
\text { Education } \\
\end{array}$ & 32 & 3.56 & 1.11 & & & & & \\
\hline & & Total & 191 & 3.98 & .89 & & & & & \\
\hline & \multirow{4}{*}{$\begin{array}{l}\text { Motivation and } \\
\text { taking } \\
\text { responsibility in } \\
\text { mathematics } \\
\text { teaching }\end{array}$} & $\begin{array}{l}\text { Pre-school Teacher } \\
\text { Education } \\
\end{array}$ & 38 & 3.67 & .67 & \multirow{4}{*}{188} & \multirow{4}{*}{1.450} & & & \\
\hline & & Child Development & 21 & 3.64 & .59 & & & 237 & 015 & _ \\
\hline & & $\begin{array}{c}\text { Distance Pre-school Teacher } \\
\text { Education }\end{array}$ & 32 & 3.44 & .789 & & & .231 & . 013 & - \\
\hline & & Total & 191 & 3.63 & .68 & & & & & \\
\hline & & $\begin{array}{c}\text { Pre-school Teacher } \\
\text { Education } \\
\end{array}$ & 38 & 4.04 & .78 & & & & & \\
\hline & Effective & Child Development & 21 & 3.98 & .99 & & & & & \\
\hline & $\begin{array}{l}\text { mathematics } \\
\text { teaching }\end{array}$ & $\begin{array}{c}\text { Distance Pre-school Teacher } \\
\text { Education }\end{array}$ & 32 & 3.63 & 1.09 & 188 & 2.904 & .057 & .030 & - \\
\hline & & Total & 191 & 3.96 & .87 & & & & & \\
\hline & & $\begin{array}{l}\text { Pre-school Teacher } \\
\text { Education }\end{array}$ & 38 & 3.88 & .65 & & & & & \\
\hline & Teta & Child Development & 21 & 3.90 & .76 & 188 & 3177 & & & 1,3 \\
\hline & Total & $\begin{array}{c}\text { Distance Pre-school Teacher } \\
\text { Education } \\
\end{array}$ & 32 & 3.53 & .81 & 188 & 3.170 & $.044^{*}$ & .033 & $1-3$ \\
\hline & & Total & 191 & 3.83 & .70 & & & & & \\
\hline
\end{tabular}

As seen in Table 6, the Tukey's HSD test results showed that there was a significant difference at two sub-dimensions of STEBI scores of pre-school teachers according to their graduation program. In terms of department that they graduated from 
university, significant differences in "personal self-efficacy belief in science teaching" scores were found in favor of pre-school teacher education compared to open education pre-school teacher education; significant differences in "result expectation in science teaching" scores were detected in favor of pre-school teacher education compared to open education pre-school teacher education and in favor of child development compared to open education pre-school teacher education. However, the Tukey's HSD test results showed that there was a significant difference at a sub-dimension of MTEBI scores of pre-school teachers according to their graduation program. In terms of department that they graduated from university, significant differences in "efficacy in mathematics teaching" scores were found in favor of pre-school teacher education compared to open education pre-school teacher education.

One-way MANOVA analysis for STEBI and MTEBI scores of pre-school teachers are presented in Table 7 according to the time period which was allocated for science and mathematics activities per week.

As seen in Table 7, there is a significant difference between STEBI scores of pre-school teachers according to the time period allocated for science activities [Wilks Lambda $(\Lambda)=0.846, F(4,374)=8.154, p=0.000, \eta^{2}=0.080$ for STEBI] However, there was no significant difference between MTEBI scores of pre-school teachers according to the time period which was allocated for science activities [Wilks Lambda $(\Lambda)=0.932, \mathrm{~F}(8,370)=1.659, \mathrm{p}=0.107, \eta^{2}=0.035$ for MTEBI] .

Table 7. The results of one-way MANOVA test performed to determine whether there was a difference on STEBI and MTEBI scores of pre-school teachers according to the time period which was allocated for science and mathematics activities per week

\begin{tabular}{|c|c|c|c|c|c|c|c|c|}
\hline Instruments & \multicolumn{2}{|l|}{ Effect } & Values & $\mathrm{F}$ & Hypothesis df & Error df & $\mathrm{P}$ & $\eta^{2}$ \\
\hline STEBI & \multirow{2}{*}{$\begin{array}{l}\text { the time period which is allocated for } \\
\text { science and mathematics activities }\end{array}$} & \multirow{2}{*}{$\begin{array}{l}\text { Wilks' } \\
\text { Lambda }\end{array}$} & .846 & 8.154 & 4.000 & 374.000 & $.000 *$ & .080 \\
\hline MTEBI & & & .932 & 1.659 & 8.000 & 370.000 & .107 & .035 \\
\hline
\end{tabular}

$* \mathrm{p}<0.05$

One-way MANOVA analysis for STEBI and MTEBI scores of pre-school teachers is presented in Table 8 according to the time period which is allocated for science and mathematics activities per week.

Table 8. The results of one-way MANOVA test performed to reveal whether there was a difference both STEBI and MTEBI scores of pre-school teachers according to the time period which is allocated for science and mathematics activities

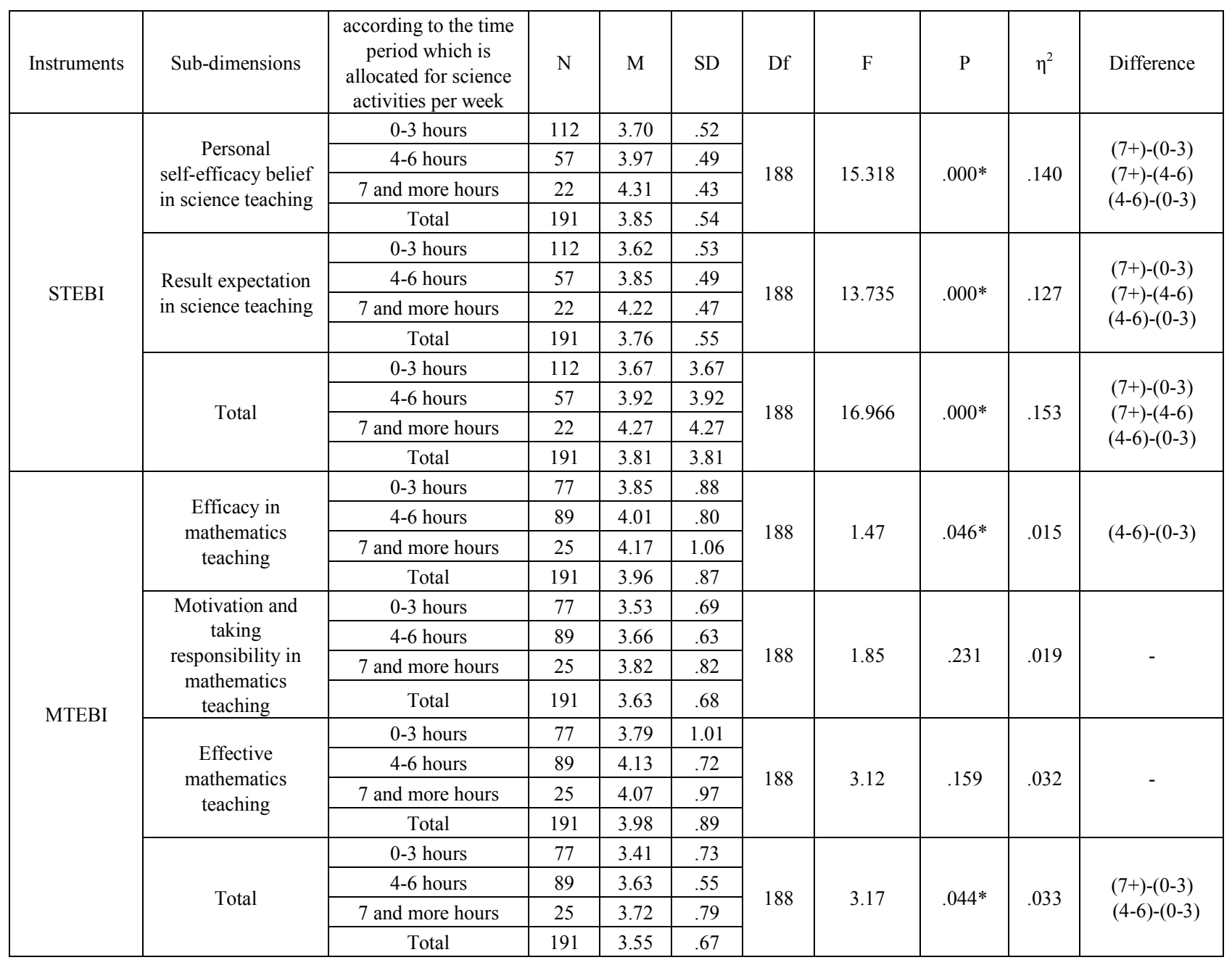


As seen in Table 8, the Tukey's HSD test results show that there is a significant difference at two sub-dimensions of STEBI scores of pre-school teachers according to the time period which was allocated for science activities. In terms of time period which was allocated for science activities, significant differences in "personal self-efficacy belief in science teaching" scores were found in favor of (7 and more) hours compared to (0-3) hours, in favor of (7 and more) hours compared to (4-6) hours and in favor of (4-6) hours compared to (0-3) hours, and significant differences in "result expectation in science teaching" scores were detected in favor of (7 and more) hours compared to (0-3) hours, in favor of (7 and more) hours compared to (4-6) hours and in favor of (4-6) hours compared to (0-3) hours. However, the Tukey's HSD test results showed that there was a significant difference at a sub-dimension of MTEBI scores of pre-school teachers according to their departments that they graduated from university. In terms of the time period which was allocated for science activities, significant differences in "efficacy in mathematics teaching" scores were revealed in favor of (4-6) hours compared to (0-3) hours.

One-way MANOVA analysis for STEBI and MTEBI scores of pre-school teachers according to their workplace is presented in Table 9.

Table 9. The results of one-way MANOVA test performed to determine whether there was a difference on STEBI and MTEBI scores of pre-school teachers according to their workplace

\begin{tabular}{|c|c|c|c|c|c|c|c|c|}
\hline Instruments & \multicolumn{2}{|c|}{ Effect } & Values & $\mathrm{F}$ & Hypothesis df & Error df & $\mathrm{p}$ & $\eta^{2}$ \\
\hline STEBI & \multirow{2}{*}{ Workplace } & \multirow{2}{*}{ Wilks' Lambda } & .991 & .824 & 2.000 & 188.000 & .440 & .009 \\
\hline MTEBI & & & .974 & 1.237 & 4.000 & 186.000 & .297 & .026 \\
\hline
\end{tabular}

$* \mathrm{p}<0.05$

As seen in Table 9, workplace had not an effect on pre-school teachers' STEBI and MTEBI scores and on pre-school teachers' scores of all sub-dimensions of STEBI and MTEBI [Wilks Lambda $(\Lambda)=0.991, F(2,188)=0.824, p=0.440$, $\eta^{2}=0.009$ for STEBI; Wilks Lambda $(\Lambda)=.974, \mathrm{~F}(4,186)=1.237, \mathrm{p}=0.297, \eta^{2}=0.026$ for MTEBI]. One-way MANOVA analysis for STEBI and MTEBI scores of pre-school teachers according to their workplace is presented in Table 10.

Table 10. A one-way MANOVA analysis for STEBI and MTEBI scores of pre-school teachers according to their workplace

\begin{tabular}{|c|c|c|c|c|c|c|c|c|c|}
\hline Instrument & Sub-dimensions & Workplace & $\mathrm{N}$ & $\mathrm{M}$ & $\mathrm{SD}$ & Df & $\mathrm{F}$ & $\mathrm{p}$ & $\eta^{2}$ \\
\hline \multirow{9}{*}{ STEBI } & \multirow{3}{*}{$\begin{array}{l}\text { Personal self-efficacy belief in } \\
\text { science teaching }\end{array}$} & Rural & 36 & 3.76 & .46 & \multirow{3}{*}{189} & \multirow{3}{*}{1.359} & \multirow{3}{*}{.245} & \multirow{3}{*}{.007} \\
\hline & & Urban & 155 & 3.88 & .56 & & & & \\
\hline & & Total & 191 & 3.85 & .54 & & & & \\
\hline & \multirow{3}{*}{$\begin{array}{l}\text { Result expectation in science } \\
\text { teaching }\end{array}$} & Rural & 36 & 3.66 & .52 & \multirow{3}{*}{189} & \multirow{3}{*}{1.528} & \multirow{3}{*}{.218} & \multirow{3}{*}{.008} \\
\hline & & Urban & 155 & 3.78 & .55 & & & & \\
\hline & & Total & 191 & 3.76 & .55 & & & & \\
\hline & \multirow{3}{*}{ Total } & Rural & 36 & 3.71 & .46 & \multirow{3}{*}{189} & \multirow{3}{*}{1.631} & \multirow{3}{*}{.203} & \multirow{3}{*}{.009} \\
\hline & & Urban & 155 & 3.83 & .52 & & & & \\
\hline & & Total & 191 & 3.81 & .51 & & & & \\
\hline \multirow{12}{*}{ MTEBI } & \multirow{3}{*}{$\begin{array}{l}\text { Efficacy in mathematics } \\
\text { teaching }\end{array}$} & Rural & 36 & 3.81 & .79 & \multirow{3}{*}{189} & \multirow{3}{*}{.121} & \multirow{3}{*}{.729} & \multirow{3}{*}{.001} \\
\hline & & Urban & 155 & 4.00 & .89 & & & & \\
\hline & & Total & 191 & 3.96 & .87 & & & & \\
\hline & \multirow{3}{*}{$\begin{array}{l}\text { Motivation and taking } \\
\text { responsibility in mathematics } \\
\text { teaching }\end{array}$} & Rural & 36 & 3.67 & .63 & \multirow{3}{*}{189} & \multirow{3}{*}{1.270} & \multirow{3}{*}{.261} & \multirow{3}{*}{.007} \\
\hline & & Urban & 155 & 3.62 & .70 & & & & \\
\hline & & Total & 191 & 3.63 & .68 & & & & \\
\hline & \multirow{3}{*}{$\begin{array}{l}\text { Effective mathematics } \\
\text { teaching }\end{array}$} & Rural & 36 & 3.83 & .91 & \multirow{3}{*}{189} & \multirow{3}{*}{1.339} & \multirow{3}{*}{.249} & \multirow{3}{*}{.007} \\
\hline & & Urban & 155 & 4.02 & .88 & & & & \\
\hline & & Total & 191 & 3.98 & .89 & & & & \\
\hline & \multirow{3}{*}{ Total } & Rural & 36 & 3.48 & .59 & & & & \\
\hline & & Urban & 155 & 3.57 & .69 & 189 & .598 & .440 & .003 \\
\hline & & Total & 191 & 3.55 & .67 & & & & \\
\hline
\end{tabular}

As seen Table 10, the Tukey's HSD test results show that there is no significant difference on all sub-dimensions both in STEBI and MTEBI of pre-school teachers according to their workplace. 


\section{Discussion and Conclusions}

In this part, the results regarding the self-efficacy beliefs of pre-school teachers toward science and mathematics teaching were discussed through a comparison with the related studies in this research area. The results of the current study indicated that the self-efficacy beliefs of pre-school teachers toward science and mathematics teaching were at a high level. Similarly, pre-school teachers' levels of self-efficacy were found high in some studies ([26]; [27]; [28]). However, pre-school teachers were not found competent enough with material development in science and science topics ([39]; [40]). In addition, pre-school teachers encountered some problems with teaching mathematics, and they viewed learning of mathematics as passively receiving of knowledge ([29]). This result should be cautiously interpreted because many pre-service teachers were more likely to be confident in themselves than they really were ([43]). This might be valid for in-service teachers as well.

Furthermore, the rank of the teachers was found to be a statistically insignificant factor ( $p>05)$ according to the scores that pre-school teachers took from the whole scale and the sub-categories of the scale. In a detailed look, the arithmetic mean statistics were examined and compared with each other. As can be understood from the arithmetic means, the pre-school teachers who had experience between zero and five years had lower self-efficacy beliefs in all sub-factors of both science and mathematics teaching compared to the other teachers who had more experience. These results can be predicted as the lack of newly appointed teachers in delivering lectures. Similarly, pre-school teachers' self-efficacy levels do not significantly differ on seniority ([26]; [27]; [28]; [30]). But, Elmas and Kanmaz [28] found out that pre-school teachers, who have at least 21 years of teaching experience, had higher levels of self-efficacy for teaching science. Another two studies revealed that pre-school teachers, who have 16-20 years of teaching experience, had the highest levels of self-efficacy ([26]; [27]). Therefore, the reasons behind the fact that newly appointed pre-school teachers have lower self-efficacy beliefs toward science and mathematics teaching can be scrutinized in a detailed way.

Another result of the current study was that the self-efficacy belief of the pre-school teachers toward science and mathematics teaching differ related to the graduation program. For instance, this statistically significant difference was detected between the face-to-face pre-school education and the distance pre-school education in the favor of face-to-face pre-school education. Another statistically significant difference was found between the face-to-face child development program and the distance pre-school education in favor of the face-to-face child development program. These statistically significant differences on the self-efficacy beliefs of pre-school teachers toward science and mathematics teaching might be related to the way that the courses are presented through face-to-face programs. Kesgin [27] found out that pre-school teachers' levels of self-efficacy did not significantly differ on the department they graduated from, but pre-school teachers, who earned a bachelor's degree from a 4-year college in Child Development, had the highest level of self-efficacy.

The results also indicated that the self-efficacy beliefs of the pre-school teachers toward science and mathematics teaching differed in terms of the time period that was allocated for science and mathematics activities per week. This statistically significant difference was found to be between the teachers who give more and less time for the science and mathematics activities in favor of the ones who gave more time for the science and mathematics activities. This statistically significant difference might be related to their competence at science and mathematics activities. This is a clear result of the fact that they give more time for mathematics and science teaching activities. This might be accounted for the fact that the use of mathematics in everyday life is more abstract than the use of science in pre-school education. The findings of Çınar [39]'s study showed that most pre-school teachers organize science and nature activities offered in the pre-school curriculum, but some did not because of insufficiency of pre-service pre-school teacher education in terms of teaching science.

In conclusion, the results showed there was no a significant difference at all sub-dimensions both STEBI and MTEBI of pre-school teachers according to their workplace. Similarly, Gömleksiz and Serhatlığlu [26] found out that pre-school teachers' levels of self-efficacy did not statistically differ on the workplace. But, they highlighted that pre-school teachers, who were teaching in schools of middle socioeconomic status, had the highest level of self-efficacy.

\section{Acknowledgements}

We are very grateful to experts for their appropriate and constructive suggestions to improve this template.

\section{REFERENCES}

[1] Riggs, I. M., \& Enochs, L. G. (1990). Toward the development of an elementary teacher's science teaching efficacy belief instrument. Science Education, 74 (69), 625-637.

[2] Özkan, Ö., Tekkaya, C. ve Çakıroğlu, J. (2002). Fen bilgisi aday ögretmenlerin fen kavramlarını anlama düzeyleri, fen ögretimine yönelik tutum ve öz yeterlik inançları. V. Fen ve Matematik Kongresi, Ankara.

[3] Dede, Y. (2008). Matematik öğretmenlerinin öğretimlerine yönelik öz-yeterlik inançları. Türk Eğitim Bilimleri Dergisi, 6(4), 741-757.

[4] Bandura, A. (2004). Health Promotion by social cognitive means. Health Education and Behaviour, 31, 143-164. 
[5] Markic, S., \& Eilks, I. (2008). A case study on German first year chemistry student teachers' beliefs about chemistry teaching, and their comparison with student teachers from other science teaching domains. Chemistry Education Research and Practice, 9, 25-34.

[6] Özdemir, S. M. (2008). Sınıf öğretmeni adaylarının öğretim sürecine ilişkin öz-yeterlik inançlarının çeşitli değişkenler açısından incelenmesi, Kuram ve Uygulamada Eğitim Yönetimi, (54), 277-306.

[7] Barut, E. (2011). İlköğretim II. kademe sosyal bilgiler öğretmenlerinin özyeterliliklerinin çeşitli değişkenler açısından incelenmesi (Ankara İli Örneği). Yayınlanmamış Yüksek Lisans Tezi. Niğde Üniversitesi Sosyal Bilimler Enstitüsü, Niğde.

[8] Flores, I. M. (2015). Developing preservice teachers' self-efficacy through field-based science teaching practice with elementary students. Research in Higher Education.

[9] Pajares, F. \& Kranzler, J. (1995). Self-efficacy beliefs and general mental ability in mathematical problem-solving. Contemporary Educational Psychology, 20(4), 426-443.

[10] Özkan,Ö., Tekkaya, C. ve Çakıroğlu, J. (2004). Fen bilgisi aday öğretmenlerin fen kavramlarını anlama düzeyleri, fen öğretimine yönelik tutum ve öz yeterlik inançları. V. Ulusal Fen Bilimleri ve Matematik Eğitimi Kongresi 16-18 Eylül 2002. Bildiriler Kitab1. Cilt.2, 1300-1304. Ankara: Devlet Kitapları Müdürlüğü Basımevi.

[11] Yıldız-Duban, N. \& Gökçakan, N. (2012). Sınıf öğretmeni adaylarının fen öğretimi öz-yeterlik inançları ve fen öğretimine yönelik tutumları. Ç.Ü. Sosyal Bilimler Enstitüsü Dergisi, Cilt 21, Sayı 1, 2012, Sayfa 267-280

[12] Fine, J., Zygouris-Coe, V., Senokossoff, G., \& Fang, Z. (2011). Secondary teachers' knowledge, beliefs, and selfefficacy to teach reading in the content areas: Voices following professional development. In M. S. Plakhotnik, S. M. Nielsen, \& D. M. Pane (Eds.), Proceedings of the Tenth Annual College of Education \&GSN Research Conference (pp. 24-28). Miami: Florida International University. http://coeweb.fiu.edu/research_conference/

[13] Henson, R. K. (2001). Teacher self-efficacy: Substantive implications and measurement dilemmas. Annual Meeting of the Educational Research Exchange, Texas.

[14] Guo, Y., Connor, C. M., Yang, Y., Roehrig, A. D., \& Morrison, F. J. (2012). The effects of teacher qualification, teacher self-efficacy, and classroom practices on fifth graders' literacy outcomes. The Elementary School Journal, 113(1), $3-24$.

[15] Jovanović, L., Kudláček, M., Block, M. E., \& Djordjević, I. (2015). Self-efficacy of pre-service physical education teacher toward teaching students with disabilities in general physical education classes in Serbia. European Journal of Adapted Physical Activity, 7(2).

[16] Hackett, G., \& Betz, N. E. (1989). An exploration of the mathematics self-efficacy/mathematics performance correspondence. Journal for research in Mathematics Education, 20(3), 261-273.

[17] Peker, M. (2016). Mathematics teaching anxiety and self-efficacy beliefs toward mathematics teaching: A path analysis. Educational Research and Reviews, 11(3), 97-104.
[18] Palmer, D., Dixon, J. \& Archer, J. (2015). Changes in Science Teaching Self-efficacy among Primary Teacher Education Students. Australian Journal of Teacher Education. 40(12), 27-40.

[19] Yaman, s., Cansüngü-Koray, Ö. ve Altunçekiç, A. (2004). Fen bilgisi öğretmen adaylarının öz-yeterlik inanç düzeylerinin incelenmesi üzerine bir araştırma, www.tebd.gazi.edu.tr/arsiv/2004_cilt2/sayi_3/355-366.pdf (Erişim Tarihi: 20.06.2016).

[20] National Council of Teachers of Mathematics. (1980). An agenda for action: Recommendations for school mathematics of the 1980s. Reston, VA: National Council of Teachers of Mathematics.

[21] National Science Teachers Association. (1983). Position statement on science-technology-society: Science education for the 1980s. In Science teaching: A profession speaks, ed. F.K. Brown and D.P. Butts. Washington, D.C.: National Science Teachers Association.

[22] Ostlund, K. (1998). What research says about science process skills: How can teaching science process skills improve student performance in reading, language arts, and mathematics? Electronic Journal of Science Education, 2(4).

[23] Buss, R. R. (2010). Efficacy for teaching primary science and mathematics compared to other content. School Science and Mathematics, $110(6)$ 290-297.http://dx.doi.org/10.1111/j.1949-8594.2010.00037.x

[24] French, L. (2004). Science as the center of a coherent, integrated early childhood curriculum. Early Childhood Research Quarterly, 19(1), 138-149.

[25] Chung, L., Marvin, A.C. \& Churchill, S. L. (2005). Teachers' factors associated with pre-school teacher-child relationships: teaching efficacy and parent-teacher relationships. Journal of Early Childhood Teacher Education, 25, 131-142.

[26] Gömleksiz, M.N. \& Serhatlıŏlu, B. (2013). Okul öncesi öğretmenlerinin öz-yeterlik inançlarina ilişkin görüşleri. Turkish Studies - International Periodical For The Languages, Literature and History of Turkish or Turkic. 8(7), 201-221.

[27] Kesgin, E. (2006). Okul öncesi eğitim öğretmenlerinin öz-yeterlik düzeyleri ile problem çözme yaklaşımlarını kullanma düzeyleri arasındaki ilişkinin incelemesi (Denizli ili örneği). (Yayınlanmamış Yüksek Lisans Tezi). Pamukkale Üniversitesi, Denizli.

[28] Elmas, H. \& Kanmaz, A. (2015). Okul öncesi eğitim öğretmenlerinin fen eğitimine ilişkin görüşlerinin belirlenmesi. Eğitim ve Öğretim Araştırmaları Dergisi, 4(2), $35-45$.

[29] Güven, B., Öztürk, Y., Karataş, İ., Arslan, S. \& Şahin, F. (2012). Okul öncesi öğretmenlerinin matematik öğrenme ve öğretmeye yönelik inançlarının sınıf ortamına yansımaları. X. Fen Bilimleri ve Matematik Eğitimi Kongresi. 27-30 Jun 2012. Niğde.

[30] Özbey, S. \& Alisinanoğlu, F. (2009). Okul Öncesi Eğitim Kurumlarında Görev Yapan Öğretmenlerin Fen Etkinliklerine İlişkin Yeterliliklerinin Bazı Değişkenlere Göre İncelenmesi. Gazi Eğitim Dergisi, 1(1-18).

[31] Aksu, H.H. (2008). Öğretmen adaylarının matematik öğretimine yönelik öz-yeterlilik inançları. Abant Ýzzet Baysal Üniversitesi Eğitim Fakültesi Dergisi. 8(2), 161-170. 
[32] Alabay, E. (2006). İlköğretim okul öncesi öğretmen adaylarının fen ile ilgili öz yeterlik inanç düzeylerinin incelenmesi. Yedi Tepe Üniversitesi Eğitim Fakültesi Dergisi, 2(1), 30-40.

[33] Ekinci-Vural, D. \& Hamurcu, H. (2008). Okul öncesi öğretmen adaylarının fen öğretimi dersine yönelik öz-yeterlik inançları ve görüşleri. İlköğretim Online, 7(2), 456-467.

[34] İnan, C. (2014). Okul öncesi öğretmen adaylarının matematik dersini öğretebilme konusunda hazır bulunuşluk düzeylerinin değerlendirilmesi ( Diyarbakır il örneği). Turkish Studies, 9(8), 537-550.

[35] Okur-Akçay, N. (2015). Okulöncesi öğretmen adaylarının fen öğretimi öz-yeterlik inançlarının çeşitli değişkenlere göre incelenmesi. Route Educational and Social Science Journal 2(4), 268-275.

[36] Olgan, R., Güner-Alpaslan, Z. \& Öztekin, C. (2014). Okul öncesi öğretmen adaylarinin fen öğretimine yönelik sonuç beklentisi inançlarini etkileyen faktörler. Eğitim ve Bilim. 39(173). 288-300.

[37] Watters, J. J., \& Ginns, I. S. (1995). Origins of, and changes in pre-service science teaching self efficacy. Paper presented at the Annual Meeting of National Association for Research in Science Teaching, San Francisco, CA.

[38] Tortop, H.S. \& Eker, C. (2014). Öğretmen adaylarının fen öğretimi özyeterlilikleri ile fen öğrenimi öz-düzenlemeli öğrenme becerileri arasındaki ilişkinin incelenmesi. Dicle Üniversitesi Ziya Gökalp Eğitim Fakültesi Dergisi, 22 (2014) 168-184.

[39] Çınar, S. (2013). Okul öncesi öğretmenlerin fen ve doğa konularının öğretiminde kullandıkları etkinliklerin belirlenmesi. Eğitim ve Öğretim Araştırmaları Dergisi, 2(1), 364-371.

[40] Karaer \& Kösterilioğlu (2005), Amasya ve Sinop illerinde çalışan okulöncesi öğretmenlerin fen kavramlarının öğretilmesinde kullandıkları yöntemlerin belirlenmesi, Kastamonu Eğitim Dergisi, (2), 447-454.

[41] Büyüköztürk, Ş., Çakmak, E. K., Akgün, Ö. E., Karadeniz, Ş. \& Demirel, F. (2011). Bilimsel araştırma yöntemleri. (Onuncu Bask1), Ankara: Pegem Akademi.

[42] Büyüköztürk, Ş. (2002). Veri analizi el kitabı. Ankara: Pegema Yayınları.

[43] Wheatley, K. F. (2005). The case for reconceptualising teacher efficacy research. Teaching and Teacher Education, 21, 747-766.

* The part of this paper was presented in 8th World Conference on Educational Sciences, 4-8 February 2016, Madrid-Spain. 